\title{
Portable meters for nutritional assessment in plants of gerbera fertigated with electrical conductivity levels
}

\author{
Poliana R. D'A. Mota' ${ }^{1}$, Roberto L. Villas Bôas², Fernanda Ludwig ${ }^{3}$, \\ Dirceu M. Fernandes ${ }^{4} \&$ Marcos V. Folegatti ${ }^{5}$

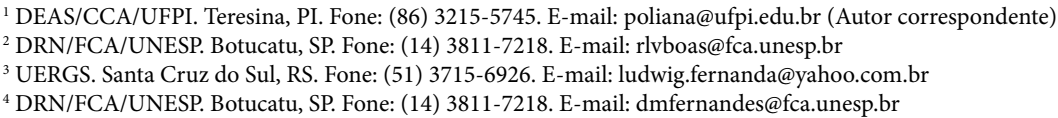

\section{Key words:}

Gerbera jamesonii L.

chlorophyll

leaf sap

solution of the substrate

\begin{abstract}
A B S T R A C T
Rapid tests to assess the nutritional status of plants gerbera can make easier the decision of any adjustments in the fertilization of the substrate. The study was conducted to evaluate nutritionally fertigated gerbera plants with increasing levels of electrical conductivity (EC), using portable meters nitrate and potassium, and chlorophyll. For this, two experiments were conducted. A randomized block design with five levels of EC $(0.5,2.0,3.5,5.0$ and 6.5 $\mathrm{dS} \mathrm{m}^{-1}$ ) and four replications was used. Cherry cultivar was used in the first experiment. In the second experiment, two cultivars (Cherry and Salmon Rose) were used. In the first experiment, the sap of the leaves was subjected to rapid testing of $\mathrm{N}_{-} \mathrm{NO}_{3}^{-}$(equipment Cardy Horiba C -141). $\mathrm{N}^{-\mathrm{NO}_{3}}{ }^{-}$and $\mathrm{K}^{+}(\mathrm{C}-131)$ were determined in the substrate solution. The intensity of the green leaf, in the second experiment was evaluated with portable Chlorophyll Meter. The $\mathrm{N}$ content in the indicator leaf in the first and $\mathrm{N}$ and $\mathrm{K}$ contents in the plant in the second experiment were determined. Rapid tests are presented as good indicators of the level of $\mathrm{N}_{-} \mathrm{NO}_{3}{ }^{-}$and $\mathrm{K}^{+}$in plant tissue, with the advantages of convenience and speed of determination, facilitating monitoring of fertilization of the substrate by producers and technicians.
\end{abstract}

\section{Palavras-chave:}

Gerbera jamesonii L.

clorofila

seiva da folha

solução do substrato

\section{Medidores portáteis para avaliação nutricional em plantas de gérbera fertirrigada com níveis de condutividade elétrica}

\begin{abstract}
R E S U M O
Os testes rápidos para avaliação do estado nutricional de plantas de gérbera podem tornar mais fácil a decisão de eventuais ajustes na fertilização do substrato. O estudo foi conduzido com o objetivo de se avaliar, nutricionalmente, plantas de gérbera fertirrigadas com níveis crescentes de condutividade elétrica (CE), utilizando-se medidores portáteis de nitrato e potássio, além de clorofilômetro. Para isto foram realizados dois experimentos. Utilizou-se um delineamento em blocos casualizados com cinco níveis de $\mathrm{CE}\left(0,5 ; 2,0 ; 3,5 ; 5,0\right.$ e $\left.6,5 \mathrm{dS} \mathrm{m}^{-1}\right)$ e quatro repetições. A cultivar Cherry foi utilizada no primeiro experimento e no segundo, duas cultivares (Cherry e Salmon Rose). No primeiro experimento a seiva das folhas foi submetida ao teste rápido de $\mathrm{N}^{-\mathrm{NO}_{3}}$ - (equipamento Cardy Horiba C-141). Determinaram-se $\mathrm{N}_{-} \mathrm{NO}_{3}{ }^{-}$e $\mathrm{K}^{+}(\mathrm{C}-131)$ na solução do substrato. Avaliou-se a intensidade da cor verde da folha no segundo experimento, com medidor portátil Chlorophyll Meter. Determinou-se o teor de $\mathrm{N}$ na folha diagnóstico no primeiro e no segundo experimento $\mathrm{N}$ e $\mathrm{K}$ da planta. Os testes rápidos se apresentam como bons indicadores do teor de ${\mathrm{N}-\mathrm{NO}_{3}}^{-}$e $\mathrm{K}^{+}$no tecido vegetal tendo como vantagens a praticidade e a velocidade de determinação facilitando o monitoramento da fertilização do substrato por produtores e técnicos.
\end{abstract}

\section{INTRODUCTION}

Gerbera (Gerbera jamesonii L.) is one of the several cultivated species of economic importance to agriculture and according to Ludwig et al. (2011) has gained prominence in the market of flower and ornamental plant. It's a plant with good durability, resistance to transport and high appreciation by consumers. However, despite the expansion of commercial production of flowers and ornamental plants, research has not been conducted at the same rhythm, especially with regard to nutrition and fertilization (Guerrero et al., 2012).

The nitrogen $(\mathrm{N})$ is often considered as the most important limiting factor, after water deficit, for biomass production in natural ecosystems (Lemaire et al., 2008). The early detection of the $\mathrm{N}$ deficiency and the timely and appropriate $\mathrm{N}$ application are important field management practices (Wu et al., 2007).

Sap analysis has been considered as a helpful to determine the better time of sampling, as demonstrated by Lozano (1996). 
According to these authors it is a fairly accurate and sensitive technique to determine the nutrient demand at various stages of development, which is the base of the program of nutrition through fertigation. Chemical determination of the sap is advantageous due to its speed and accuracy, making changes more agile in fertilization when necessary.

Plant sap can be extracted by pressure and then nitrate concentration can be immediately estimated by the use of rapid test (Lemaire et al., 2008). The extract can be analysed in the laboratory or in the field, using specific kits for analysis of $\mathrm{N}^{-\mathrm{NO}_{3}}$ - and $\mathrm{K}^{+}$. The method of analysis of the sap is used in Spain in different crops (Cadahia \& Lucena, 2005). In Brazil, some researches have been carried out and, despite difficulties in interpreting the results, sap analysis has shown to have greater sensitivity and advantages over other foliar analysis.

Another technique used in fertilizer management is the indirect measurement of chlorophyll in leaves as an indicator of the level of nitrogen in plants. According to Argenta et al. (2001), the methods used to determine the amount of leaf chlorophyll require destruction of tissue samples and much work in the process of its attainment. The usual methods of chlorophyll determination are destructive, time consuming and are made in laboratory, which precludes its use for predicting excess or deficiency of $\mathrm{N}$. With the invention of a portable meter (SPAD-502, Minolta Corporation LTD, Osaka, Japan, 1989) which analyses the leaf greenness, it is possible to obtain indirect values of chlorophyll present in leaves nondestructively, quickly and simply.

In various crops the existence of the correlation between the greenness (SPAD) and N content in the plant has been proven. According to Piekielek \& Fox (1992), the biggest benefit of the SPAD-502 is the sampling of a production area in minutes, culminating in getting immediate response to an appropriate nutritional management. The chlorophyll in the plant reaches maximum values and may indicate the point from which there is no response to $\mathrm{N}$ fertilization, unlike the content in the plants because they can absorb more $\mathrm{N}$ than need (luxury uptake). The SPAD reading may be a reference to application of fertilizers.

The study was conducted to evaluate nutritionally gerbera plants fertigated with increasing electrical conductivity levels, using portable meters of nitrate $\left(\mathrm{N}^{-\mathrm{NO}_{3}}{ }^{-}\right)$, potassium $\left(\mathrm{K}^{+}\right)$and leaf greenness and its relationship with the total concentration of $\mathrm{N}$ e K.

\section{Material ANd Methods}

The experiment was conducted at the Department of Natural Resources/Soil Science, Faculty of Agronomic Sciences, UNESP - Campus of Botucatu, São Paulo State, located between the parallels $22^{\circ} 30^{\prime}$ and $23^{\circ} 05^{\prime}$ south, latitude and meridians $48^{\circ}$ $15^{\prime}$ and $48^{\circ} 52^{\prime}$ west, longitude $\mathrm{Gr}$, and mean altitude of $830 \mathrm{~m}$.

The research consisted of two cultivation cycles, carried out in a greenhouse. Its total area was of $168 \mathrm{~m}^{2}(7 \times 24 \mathrm{~m})$ and 2.6 $\mathrm{m}$ of height. The environment had, a low roof of transparent plastic, lateral surfaces of screen with $150 \mu \mathrm{m}$, and was paved with concrete.

The greenhouse was equipped with thermo-reflective mesh with $50 \%$ shading (Aluminet). The control of opening and closing Aluminet was carried out according to the readings during the day using a portable digital light meter Instrutherm brand, model LD 200, to maintain the crop in the range from 40,000 to 45,000 lux.

In the first cultivation cycle, a randomized block design was adopted with five EC levels $\left(0.5,2.0,3.5,5.0\right.$ and $\left.6.5 \mathrm{dS} \mathrm{m}^{-1}\right)$ with four replications. The Cherry cultivar was used. In the second, a randomized block design was adopted. The treatments consisted of a factorial $5 \times 2$, with five EC levels $(0.5,2.0,3.5,5.0$ and 6.5 $\mathrm{dS}^{-1}$ ) and two cultivars (Cherry and Salmon Rose) which were replicated four times. These cultivars were chosen because they are the most widely used commercially.

The seedlings were planted in plastic pots with a volume of $1.3 \mathrm{~L}$. The substrate consisted of a mixture of $30 \%$ subsurface soil and $70 \%$ of thin pine bark, in the first experiment and $40 \%$ subsurface soil, $40 \%$ of pine bark and $20 \%$ thin bark of pine in the second experiment. The seedlings were acclimated for 30 days and distributed after the final spacing. Therefore, the results are presented in days after spacing (DAS). The plants were conducted on two wooden benches $1.2 \times 12.0 \mathrm{~m}$, arranged in a spacing of $0.30 \times 0.30 \mathrm{~m}$ at a height of $0.80 \mathrm{~m}$ on concrete floor.

The application of water was performed simultaneously with the of fertilizers, according to the EC levels for each treatment. Five different solutions were prepared, so that each plant received the pre-established quantities of nutrients and the same volume of solution. For each solution there was a line of irrigation. As sources of nutrients, the following products were used: calcium nitrate, potassium nitrate, ammonium sulfate, magnesium sulfate, ammonium monophosphate (MAP), tense coktall $(0.25 \%$ of B, $2.57 \%$ of Ca EDTA , $0.53 \%$ of Cu EDTA, $2.10 \%$ of Fe EDTA, $1.74 \%$ of Fe DTPA, 2.57\% of Mn EDTA, $0.13 \%$ of Mo and $0.53 \%$ of Zn EDTA) and chaufer ${ }^{\circ}(4.8 \%$ chelated Fe EDDHA ortho-ortho).

The management of salt concentration of the nutrient solution in the root zone of the plants was performed by withdrawal of the solution with the use of extractors. These solutions were collected twice a week and, according to the EC value obtained, amounts of salts were adjusted to be applied to the maintenance of the EC according to respective treatment. The solutions were handled in a way that the average of both cultivars were maintained in the range of the tolerance of $20 \%$ above or below of the EC pre-established.

The water depth was monitored using tensiometers with mercury manometer. The irrigation was performed when the substrate water tension reached $0.015 \mathrm{MPa}$, raising water content up to the value corresponding to field capacity.

At the end of the first experiment, the leaves of gerbera of the cultivar Cherry were macerated to obtain the sap. All these samples were subjected to a rapid test for the determination of $\mathrm{N}-\mathrm{NO}_{3}{ }^{-}$, in $\mathrm{mg} \mathrm{L}^{-1}$, using the equipment Horiba Cardy C-141. 
At 28 and 56 DAS, in middle and end of the second experiment, the concentration of $\mathrm{N}^{-\mathrm{NO}_{3}}$ and $\mathrm{K}^{+}$, in $\mathrm{mg} \mathrm{L}^{-1}$ was determined in the solution, through the extract, using the Cardy Horiba C- C-141 and 131 equipment, respectively.

The leaf greenness (LG) of gerbera leaves was evaluated at 29 and 56 DAS in the second experiment, determined by portable Chlorophyll Meter, model SPAD-502 (Soil and Plant Analysis Development) of Minolta Co., Osaka, Japan. Ten leaves per plot were sampled, each plot consisted of two plants. The $\mathrm{N}$ content was determined in the diagnostic leaf (fully expanded leaf and physiologically mature) in the first experiment for the cultivar Cherry, at 56 DAS, and the content of $\mathrm{N}$ and $\mathrm{K}$ of the plant canopy at 28 and 56 DAS, in the second experiment, using the cultivars Cherry and Salmon Rose. For this analysis, the recommendation described by Malavolta et al. (1997) were followed.

The effects of the solutions levels were subjected to regression analysis, testing the linear and quadratic model, based on the significance of regression coefficients, and by highest coefficient of determination $\left(\mathrm{R}^{2}\right)$ (Ferreira, 2003). The correlation between the variables were obtained by means of the extracts along the cultivation cycles.

\section{Results AND Discussion}

The nutrient solution EC affected the concentration of $\mathrm{N}-\mathrm{NO}_{3}{ }^{-}$in the leaf sap of gerbera. The solution corresponding to the application of EC of $6.5 \mathrm{dS} \mathrm{m} \mathrm{m}^{-1}$ showed the highest concentration and the lowest value was obtained in solution with $\mathrm{EC}$ of $0.5 \mathrm{dS} \mathrm{m}^{-1}$. In Figure 1A the increasing trend of nitrate concentration with increase of $\mathrm{EC}$ is shown.

Based on the results obtained by visual inspection of the plant,

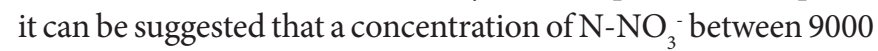
and $11000 \mathrm{mg} \mathrm{L}^{-1}$ in the leaf sap would be a first approximation suitable for the cultivation of gerbera, obtained with EC of $3.5 \mathrm{dS} \mathrm{m}^{-1}$. At this EC level the highest levels of total $\mathrm{N}$ in the diagnostic leaf were also registered (Figure 1B).

Establishing a correlation between the nitrate obtained in the gerbera leaf sap with the result of the chemical analysis of the contents in the diagnostic leaf a value of $r=0.88$ was found. These results indicate that the sap assessed by Cardy can be used to estimate the $\mathrm{N}$ content in the plant. Folegatti et al. (2005) observed that the nitrate levels measured in the leaf sap showed a good correlation with the total $\mathrm{N}$ content measured in dry matter in tomato plants.

The values of $\mathrm{N}^{-\mathrm{NO}_{3}}$ - determined in the solution obtained with the methodology of extracting solution at 28 and 56 DAS in the second experiment are presented in Table 1. For the two sampling dates, there were no significant differences between cultivars and between the EC levels, adjusting to a linear regression. There was interaction between cultivars and EC levels at 56 DAS with linear and quadratic adjustment.

The highest concentration of nitrate was obtained in the Cherry cultivar in relation to Salmon Rose, at 28 DAS, the
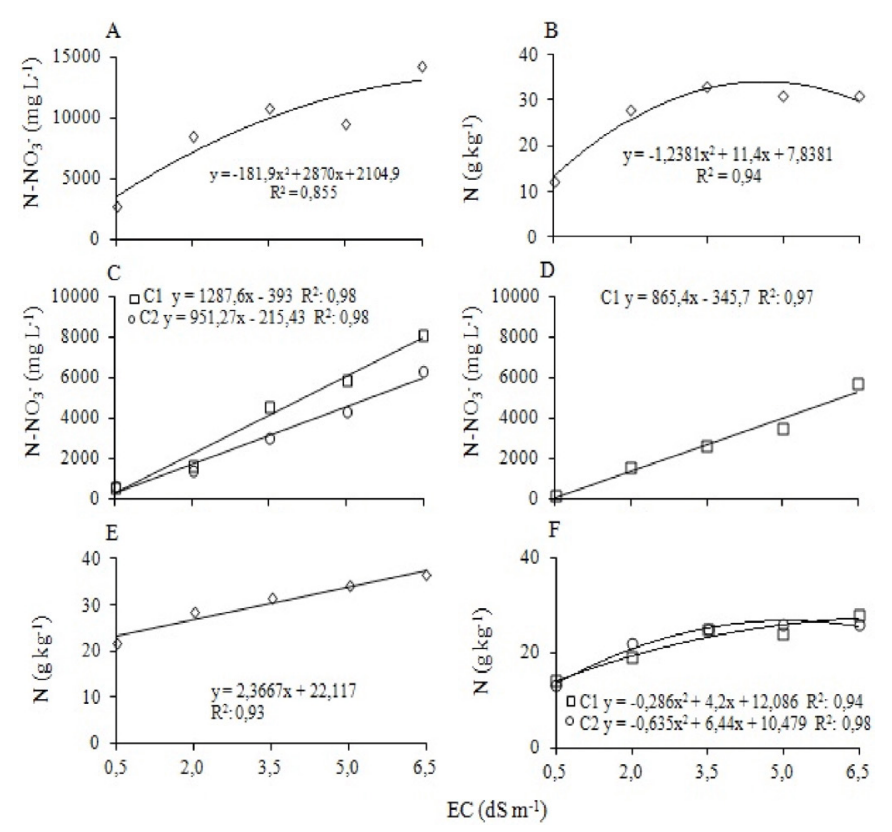

C1: Cherry. C2: Salmon Rose

Figure 1. Concentration of $\mathrm{N}-\mathrm{NO}_{3}^{-}$, in $\mathrm{mg} \mathrm{L}^{-1}$, in the sap of the leaf (A); total- $\mathrm{N}$ content, in $\mathrm{g} \mathrm{kg}^{-1}$, in the diagnosis leaf of gerbera leaf (B); Cherry cultivar at the end of the first experiment; $\mathrm{N}-\mathrm{NO}_{3}{ }^{-}$, in $\mathrm{mg} \mathrm{L}^{-1}$, of the substrate solution at 28 (C) and 56 DAS (D); total-N, in $\mathrm{g} \mathrm{kg}^{-1}$, in the dry matter of the aerial part at 28 (E) and 56 DAS (F) in the second experiment, in function of the levels of electrical conductivity (EC)

Table 1. Concentration of $\mathrm{N}^{-\mathrm{NO}_{3}}$, in $\mathrm{mg} \mathrm{L}^{-1}$, of the substrate solution obtained with the extractor solution; nitrogen content in the leaf, in $\mathrm{g} \mathrm{kg}^{-1}$; and leaf greenness, in SPAD, for the gerbera cultivars Cherry and Salmon Rose fertigated with increasing levels of electrical conductivity (EC)

\begin{tabular}{|c|c|c|c|c|c|c|c|}
\hline \multirow{4}{*}{ Cultivar } & \multirow{4}{*}{$\begin{array}{c}\text { Solution } \\
\mathrm{dS} \mathrm{m}^{-1}\end{array}$} & \multicolumn{2}{|c|}{$\mathrm{N}-\mathrm{NO}_{3}{ }^{-}$} & \multirow{2}{*}{\multicolumn{2}{|c|}{$\begin{array}{c}\text { Total N } \\
\text { DAS } \\
\end{array}$}} & \multirow{2}{*}{\multicolumn{2}{|c|}{ Leaf greenness }} \\
\hline & & & & & & & \\
\hline & & 28 & 56 & 28 & 56 & 28 & 56 \\
\hline & & \multicolumn{2}{|c|}{$\mathrm{mg} \mathrm{L}^{-1}$} & \multicolumn{2}{|c|}{$\mathrm{g} \mathrm{kg}^{-1}$} & \multicolumn{2}{|c|}{ SPAD } \\
\hline \multirow{5}{*}{ Cherry } & 0,5 & 543 & $153 a$ & 21 & $14 \mathrm{a}$ & 42,9 & 44,4 \\
\hline & 2,0 & 1575 & $1538 \mathrm{~b}$ & 30 & $19 b$ & 45,4 & 52,8 \\
\hline & 3,5 & 4550 & $2600 \mathrm{a}$ & 32 & $25 \mathrm{a}$ & 49,5 & 48,9 \\
\hline & 5,0 & 5825 & $3425 \mathrm{a}$ & 34 & $24 \mathrm{a}$ & 54,0 & 58,7 \\
\hline & 6,5 & 8075 & $5700 \mathrm{a}$ & 38 & $28 \mathrm{a}$ & 52,3 & 51,6 \\
\hline Mean & & $4114 \mathrm{~A}$ & $2683 \mathrm{~A}$ & $31 \mathrm{~A}$ & $22 \mathrm{~A}$ & $48,8 \mathrm{~B}$ & $51,3 \mathrm{~A}$ \\
\hline \multirow{5}{*}{$\begin{array}{l}\text { Salmon } \\
\text { Rose }\end{array}$} & 0,5 & 603 & $181 \mathrm{a}$ & 22 & $13 \mathrm{a}$ & 44,1 & 50,4 \\
\hline & 2,0 & 1400 & $3425 \mathrm{a}$ & 27 & $22 \mathrm{a}$ & 48,1 & 54,9 \\
\hline & 3,5 & 2967 & $1428 \mathrm{a}$ & 31 & $25 \mathrm{a}$ & 55,9 & 53,3 \\
\hline & 5,0 & 4325 & $2350 \mathrm{a}$ & 34 & $26 \mathrm{a}$ & 58,7 & 52,3 \\
\hline & 6,5 & 6275 & $1765 \mathrm{~b}$ & 35 & $26 \mathrm{~b}$ & 59,7 & 50,8 \\
\hline Mean & & $3114 \mathrm{~B}$ & $1830 \mathrm{~B}$ & $30 \mathrm{~A}$ & $22 \mathrm{~A}$ & $53,3 \mathrm{~A}$ & $52,3 \mathrm{~A}$ \\
\hline FC & & * & * & NS & NS & $\star \star$ & NS \\
\hline FS & & ** & ** & ** & ** & ** & NS \\
\hline$F C^{*} S$ & & NS & * & NS & * & NS & NS \\
\hline R S & & $L^{* *}$ & $L^{* \star}$ & $L^{* \star}, Q^{\star \star}$ & $L^{\star \star}, Q^{\star \star}$ & $L^{* *}, Q^{*}$ & NS \\
\hline$R C^{*} S$ & & $L^{* *}$ & $L^{* \star}, Q^{\star}$ & $L^{\star \star}, Q^{\star}$ & $L^{* \star}, Q^{\star *}$ & $L^{* \star}, Q^{\star}$ & NS \\
\hline
\end{tabular}

Days after the sowing (DAS); cultivar (C); solution (S); regression (R); effect significant linear (L) and quadratic $(\mathrm{Q})$; significant at $p<0.05\left(^{*}\right)$ and $p<0.01\left(^{* *}\right)$ of probability level not significant (NS); means followed by same letters in column do not differ by Tukey test at 0.05 level of probability 
opposite occurs with the N. As the electrical conductivity of the solution was increased, the concentration of nitrate in the nutrient solution showed an increasing pattern (Figure 1C) and, for the total $\mathrm{N}$ content (Figure $1 \mathrm{E}$ and $1 \mathrm{~F}$ ) similar results were obtained by Ludwig et al. (2008).

In the unfolding of the interaction between cultivars and EC levels at 56 DAS, it can be observed that the values of $\mathrm{N}^{-\mathrm{NO}_{3}}$ was significantly different for the solutions that received 2.0 and $6.5 \mathrm{dS} \mathrm{m}^{-1}$ of EC, for the Salmon Rose and Cherry cultivars, respectively. In accord with the Figure 1D, the nitrate levels increased with increase in the EC in the cultivar Cherry, unlike of the Salmon Rose cultivar, which presented the point of maximum in the EC of $2.0 \mathrm{dS} \mathrm{m}^{-1}$. Lemaire et al. (2008) suggest that the sap nitrate concentration depends on cultivar.

The correlations between the reading of nitrate using the Cardy in substrate solution, obtained with the extractor solution and the $\mathrm{N}$ content in the shoot of the plants at 28 DAS were 0.92 for the cultivar Cherry and 0.98 for the Salmon Rose. At 56 DAS, the coefficient was 0.93 for the cultivar Cherry and 0.59 for the Salmon Rose.

The leaf greenness differed between the cultivars at 29 DAS, with the higher values for the Cherry (Table 1). According to Mercurio (2002), the green color intensity in the upper leaves of gerbera depends on the cultivar.

As the EC was increased, the leaf greenness showed the same trend, at 29 DAS. However, this occurrence was not recorded at 56 DAS (Table 1). Zheng et al. (2004) found values between 45 and 52.5 SPAD in the EC of 0.2, 0.5, 1.0 and $1.7 \mathrm{dS} \mathrm{m}^{-1}$ in gerbera plants, with lower values at lower electrical conductivities levels.

The correlation coefficient between the nitrate reading with the Cardy in the substrate solution obtained by the extractor and the leaf greenness was 0.92 for cultivar Cherry and 0.93 for the Salmon Rose at 28 DAS; and 0.51 for the cultivar Cherry and 0.79 for the Salmon Rose at 56 DAS. Establishing a correlation between the reading of the leaf greenness with the $\mathrm{N}$ content in shoots of the plant at the time of fertilization vegetative exchange for the button, a value of $\mathrm{r}$ of 0.88 and 0.99 for the cultivars Cherry and Salmon Rose were obtained, respectively, reducing at 56 DAS.

Similar results were found by Wu et al. (2007) who showed that, although overall treatment variations in SPAD readings were consistent with those in petiole nitrate concentrations, SPAD readings did not respond as rapidly as sap nitrate concentrations to $\mathrm{N}$ fertilization throughout the growing season. The feasibility of the SPAD for the diagnose of the nutritional deficiency and for the need of nitrogen fertilization appears to be increased as in contrasting conditions of $\mathrm{N}$ supply (Hurtado et al., 2009).

The nitrate content during growing season reduced to the reproductive stage, corresponding with the concentration of total N (Table 1), except for the cultivar Salmon Rose under EC of $2.0 \mathrm{dS} \mathrm{m}^{-1}$. For the leaf greenness, there was no trend for all levels of electrical conductivity. Possibly, the effect in reducing the content of $\mathrm{N}$ is related to the dilution of this nutrient, with the increase of the dry matter of the plant.
The values of $\mathrm{K}^{+}$determined using the Horiba Cardy in the extractor solution at 28 and $56 \mathrm{DAS}$ are presented in Table 2. There were differences between the cultivars at 28 and 56 DAS. Also, significant difference was verified between solutions with quadratic equation at 28 DAS and linear at 56 DAS (Figure $2 \mathrm{~A}$ and B).

Higher values of $\mathrm{K}^{+}$were observed for the cultivar Cherry, about of $184 \mathrm{mg} \mathrm{L}^{-1}$ more than in the Salmon Rose, as well as increased $\mathrm{K}^{+}$concentration by increasing the EC for the two cultivars. However, for the $\mathrm{K}$ content in plant tissue, the difference between cultivars was only recorded at 28 DAS (Table 2).

The correlation between the $\mathrm{K}^{+}$concentration using the Cardy in the extractor solution and the concentration of $\mathrm{K}^{+}$in

Table 2. Concentration of $\mathrm{K}^{+}\left(\mathrm{mg} \mathrm{L}^{-1}\right)$ determined on the extractor solution and in the aerial part of gerbera plants grown with increasing levels of electrical conductivity (EC)

\begin{tabular}{|c|c|c|c|c|c|}
\hline \multirow{4}{*}{ Cultivar } & \multirow{4}{*}{$\begin{array}{l}\text { Solution } \\
\mathrm{dS}^{-1}\end{array}$} & \multicolumn{2}{|c|}{$\mathrm{K}^{+}$extractor solution } & \multicolumn{2}{|c|}{$\mathbf{K}_{\text {aerial plant }}$} \\
\hline & & \multicolumn{4}{|c|}{ DAS } \\
\hline & & 28 & 56 & 28 & 56 \\
\hline & & \multicolumn{2}{|c|}{$\mathrm{mg} \mathrm{L}^{-1}$} & \multicolumn{2}{|c|}{$\mathrm{g} \mathrm{kg}^{-1}$} \\
\hline \multirow{5}{*}{ Cherry } & 0,5 & 132 & 51 & 37 & 31 \\
\hline & 2,0 & 154 & 238 & 45 & 36 \\
\hline & 3,5 & 393 & 423 & 46 & 42 \\
\hline & 5,0 & 530 & 510 & 46 & 40 \\
\hline & 6,5 & 873 & 933 & 39 & 40 \\
\hline Mean & & $416 \mathrm{~A}$ & $431 \mathrm{~A}$ & $43 \mathrm{~A}$ & $38 \mathrm{~A}$ \\
\hline \multirow{5}{*}{$\begin{array}{l}\text { Salmon } \\
\text { Rose }\end{array}$} & 0,5 & 96 & 31 & 36 & 30 \\
\hline & 2,0 & 123 & 198 & 40 & 38 \\
\hline & 3,5 & 267 & 258 & 38 & 39 \\
\hline & 5,0 & 438 & 355 & 35 & 37 \\
\hline & 6,5 & 690 & 395 & 35 & 36 \\
\hline Mean & & $323 \mathrm{~B}$ & $247 \mathrm{~B}$ & $37 \mathrm{~B}$ & $36 \mathrm{~A}$ \\
\hline FC & & $\star$ & $\star \star$ & $\star \star$ & NS \\
\hline F S & & ** & $\star \star$ & NS & ** \\
\hline $\mathrm{FC} * \mathrm{~S}$ & & NS & NS & NS & NS \\
\hline R S & & $L^{\star \star}, Q^{\star \star}$ & $L^{* *}$ & $Q^{\star \star}$ & $L^{\star \star}, Q^{\star \star}$ \\
\hline $\mathrm{RC} \mathrm{C}^{\star} \mathrm{S}$ & & $L^{\star \star}, Q^{\star}$ & $L^{* *}$ & $Q^{* *}$ & $L^{\star \star}, Q^{\star}$ \\
\hline
\end{tabular}

Days after the sowing (DAS); cultivar (C); solution (S); regression (R); significant linear (L) and quadratic $(Q)$ effect; significance of $p<0.05\left(^{\star}\right)$ and $p<0.01\left(^{(*)}\right.$ of probability level not significant (NS); means followed by same letter in column do not differ by Tukey test at 0.05 level of probability
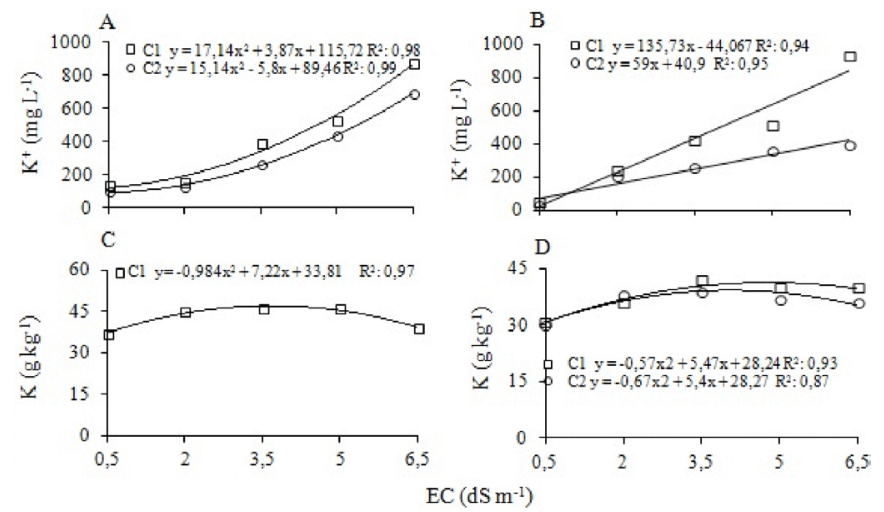

C1: Cherry. C2: Salmon Rose

Figure 2. Concentration of $\mathrm{K}^{+}\left(\mathrm{mg} \mathrm{L}^{-1}\right)$ in the substrate solution obtained using Cardy at 28 (A) and 56 DAS (B), and in the plant tissue of gerbera at $28(\mathrm{C})$ and 56 DAS (D), $\mathrm{g} \mathrm{kg}^{-1}$ 
the plant canopy at 56 DAS was 0.72 for the cultivar Cherry and 0.66 for the Salmon Rose. At the end of the growing season, no correlation was found. Regarding the $\mathrm{K}^{+}$content in plant tissue, it was found that the values were higher in the EC of $3.5 \mathrm{dS} \mathrm{m}^{-1}$, with further reduction (Figure $2 \mathrm{C}$ and $\mathrm{D}$ ).

Folegatti et al. (2005) reported high correlation between the nitrate and the potassium measured using Cardy and the standard laboratory method, in evaluation of tomato plants, noting that the use of Cardy is appropriate to evaluate the ionic concentration in soil solution, providing rapid and precise measurements for the fertigation management.

The results agree with Silva et al. (2003), who verified the possibility of determining the concentrations of nitrate and potassium in the soil solution, obtained with the use of extractor solution, with acceptable accuracy, which may promote the diagnosis of nutritional imbalances, assisting in the management of fertigation.

Further experiments with other portable meters are needed for adjustments and to corroborate results.

\section{Conclusions}

1. The rapid tests introduced for the assessment of nutritional status of gerbera present a good indicative of the $\mathrm{N}_{-} \mathrm{NO}_{3}$ and the $\mathrm{K}^{+}$levels, and also the leaf greenness, with the advantage of the convenience and speed of determination, facilitating the routine for of producers and professionals.

2. Rapid tests present high correlation with total $\mathrm{N}$ and $\mathrm{K}$ in gerbera plants.

\section{Literature Cited}

Argenta, G.; Silva, P. R. F.; Bortolini, C. G.; Forsthofer, E. L.; Strieder, M. L. Relação da leitura do clorofilômetro com os teores de clorofila extraível e de nitrogênio na folha de milho. Revista Brasileira de Fisiologia Vegetal, v.13, p.158167, 2001.

Cadahía, C.; Lucena, J. J. Diagnostico de nutrición y recomendaciones de abonado. In: Cadahía, C. Fertirrigación: Cultivos hortícolas, frutales y ornamentales. 3.ed. Madrid: Mundi-Prensa, 2005. p.183-257.

Ferreira, D. F. Sisvar versão 4.2. DEX/UFLA, 2003. 79p.

Folegatti, M. V.; Blanco, F. F.; Boaretto, R. M.; Boaretto, A. E. Calibration of Cardy-ion meters to measure nutrient concentrations in soil solution and in plant sap. Scientia Agricola, v.62, p.8-11, 2005.
Guerrero, A. C.; Fernandes, D. M.; Ludwig, F. Acúmulo de nutrientes em gérbera de vaso em função de fontes $\mathrm{e}$ doses de potássio. Horticultura Brasileira, v.30, p.201208, 2012.

Hurtado, S. M. C.; Resende, A. V.; Silva, C. A.; Corazza, E. J.; Shiratsuchi, L. S. Variação espacial da resposta do milho à adubação nitrogenada de cobertura em lavoura no cerrado. Pesquisa Agropecuária Brasileira, v.44, p.300-309, 2009.

Lemaire, G.; Jeuffroy, M. H.; Gastal, F. Diagnosis tool for plant and crop $\mathrm{N}$ status in vegetative stage theory and practices for crop $\mathrm{N}$ management. European Journal of Agronomy, v.28, p.614-624, 2008.

Lozano, E. Estudio comparativo de la deficiencia de boro y de calcio en cuatro variedades de Lyropersicon esculentum Mill. Madrid: Universidad Autónoma de Madrid, 1996. Tese Doutorado

Ludwig, F.; Fernandes, D. M.; Mota, P. R. D.; Villas-Bôas, R. L. Macronutrientes em cultivares de gérbera sob dois níveis de fertirrigação. Horticultura Brasileira, v.26, p.68-73, 2008.

Ludwig, F.; Guerrero, A. C. Fernandes, D. M.; Villas-Bôas, R. L.; Laschi, D. Qualidade de cultivares de gérbera de vaso em função das características físicas e químicas dos substratos. Revista Brasileira de Horticultura Ornamental, v.17, p.141148. 2011.

Malavolta, E.; Vitti, G. C.; Oliveira, S. A. Avaliação do estado nutricional das plantas: princípios e aplicações. Piracicaba: Potafos. 1997.319p.

Mercurio, G. Gerbera cultivation in greenhouse. The Netherlands: Schreurs. 2002. 206p.

Piekielek, W. P.; Fox, R. H. Use of a chlorophyll meter for predict sidedress requeriments for maize. Agronomy Journal, v.84, p.59-65, 1992.

Silva, E. F. F.; Duarte, S. N.; Folegatti, M. V.; Rojais, E. G. Utilização de testes rápidos e extratores de solução do solo na determinação de nitrato e potássio. Engenharia Agrícola, v.23, p.460-467, 2003.

Wu, J.; Wang, D.; Rosen, C. J.; Bauer, M. E. Comparison of petiole nitrate concentrations, SPAD chlorophyll readings, and QuickBird satellite imagery in detecting nitrogen status of potato canopies. Field Crops Research, v.101, p.96-103, 2007.

Zheng, Y.; Graham, T.; Richard, S.; Dixon, M. Potted gerbera production in a subirrigation system using lowconcentration nutrient solutions. HortScience, v.39, p.12831286, 2004. 